American Journal of Primatology 48:237-246 (1999)

\title{
Intake, Digestibility, and Passage of a Commercially Designed Diet by Two Propithecus Species
}

\author{
J.L. CAMPBELL ${ }^{1 *}$, J.H. EISEMANN ${ }^{1}$, K.E. GLANDER ${ }^{2}$, AND S.D. CRISSEY ${ }^{3}$ \\ ${ }^{1}$ Interdepartmental Nutrition Program and Department of Animal Science, North Carolina \\ State University, Raleigh, North Carolina \\ ${ }^{2}$ Department of Biological Anthropology and Anatomy, Duke University, Durham, \\ North Carolina \\ ${ }^{3}$ Chicago Zoological Society, Brookfield Zoo, Brookfield, Illinois
}

The digestibility and passage of an experimental diet was used to compare the digestive physiology of two Propithecus species: $P$. verreauxi and $P$. tattersalli. Though both animals have a similar feeding ecology, the captive status of $P$. verreauxi is considered more stable than that of $P$. tattersalli. The test diet included a local tree species, Rhus copallina, at $15 \%$ of dry matter intake (DMI) and Mazuri Leafeater Primate Diet at $85 \%$ of DMI. The chemical composition of the diet (dry matter basis) was $25 \%$ crude protein, $34 \%$ neutral detergent fiber (NDF), and $22 \%$ acid detergent fiber (ADF) with a gross energy of $4.52 \mathrm{kcal} / \mathrm{g}$. After a 6 week acclimation to the experimental diet, animals were placed in research caging. After a 7 day adjustment period, animals were dosed with chromium mordant and Co-EDTA as markers for digesta passage and all feed refusals and feces were collected at timed intervals for 7 days. Digestibility values, similar for both species, were approximately $65 \%$ for dry matter, crude protein, and energy, and $40 \%$ and $35 \%$ respectively, for NDF and ADF. Transit times (17-18.5 hr) and mean retention times (31-34 hr) were not significantly different between species, and there was no difference between the chromium mordant and Co-EDTA. Serum values for glucose, urea, and non-esterified fatty acids (NEFA) were obtained during four different time periods to monitor nutritional status. While there was no change in serum glucose, serum urea increased over time. The NEFAs increased across all four time periods for $P$. verreauxi and increased for the first three periods then decreased in the last period for $P$. tattersalli. Results obtained indicate no difference in digestibility nor digesta passage between species, and that both Propithecus species were similar to other post-gastric folivores. Am. J. Primatol. 48:237-246, 1999. () 1999 Wiley-Liss, Inc.

Key words: propithecus; folivory; digestibility; digesta passage

Contract grant sponsor: Purina Mills, Inc.

*Correspondence to: Jennifer L. Campbell, Box 7621, Department of Animal Science, North Carolina State University, Raleigh NC 27695. E-mail: jlcampbe@unity.ncsu.edu

Received 2 February 1998; revision accepted 2 February 1999

(C) 1999 Wiley-Liss, Inc. 


\section{8 / Campbell et al. \\ INTRODUCTION}

The large bodied Propithecus, diurnal folivores from the family Indridae, are among the most endangered lemur species [Mittermeier et al., 1992]. Of the three extant species, $P$. diadema, $P$. tattersalli, and $P$. verreauxi, the first two are considered endangered, and $P$. verreauxi is listed as vulnerable [Mittermeier et al., 1992]. All are threatened by habitat destruction. While $P$. verreauxi and $P$. diadema have ranges within protected areas, $P$. tattersalli does not.

Field studies indicate that $P$. verreauxi and $P$. tattersalli are folivorous primates, seasonally obtaining the majority of their nutritional needs from leaves [Hladik, 1978; Meyers, 1993; Richard, 1977; Tattersall, 1982]. Richard [1977] reported leaf consumption in P. v. verreauxi as high as $80 \%$ and Meyers [1993] reported leaf consumption values as high as $46 \%$ for $P$. tattersalli. The remainder of their diet comprises other plant components (fruits, seeds, etc.). The ability to process a large amount of leaves indicates gastrointestinal as well as dental adaptations to such a diet [Stevens \& Hume, 1995].

Currently, there are $19 P$. v. coquereli and three P. tattersalli housed in captivity. Although available information concerning feeding ecology, dentition, and gastro-intestinal morphology indicate the two species should have similar nutritional needs [Hill, 1953; Kay \& Hylander, 1978; Meyers, 1993; Richard, 1977], $P$. tattersalli has not responded well to captivity. This could, at least in part, be linked to diet and nutrition. The objective of this study was to compare the intake, digestibility. and passage of an experimental diet by the two species. Given the similarities observed for feeding ecology, dentition, and gastro-intestinal morphology, the hypothesis was that there would be no difference in the species' ability to process the diet.

\section{MATERIALS AND METHODS}

\section{Animals and Experimental Design}

Six $P$. $v$.coquereli and three $P$. tattersalli were selected for use in this experiment (see Table I for individual animal age, sex, and weight data). Experimental design included a 6 week stepwise changeover to the experimental diet, a 7 day adjustment period to the experimental caging, and a 7 day collection period fol-

TABLE I. Propithecus spp. Individual Age and Weight Data*

\begin{tabular}{lccccccc}
\hline Animal & M/F & $\begin{array}{c}\text { Age } \\
\text { (years) }\end{array}$ & $\begin{array}{c}\text { Date of } \\
\text { birth }\end{array}$ & $\begin{array}{c}\text { Start } \\
(\mathrm{g})\end{array}$ & $\begin{array}{c}\text { Pre-caging } \\
(\mathrm{g})\end{array}$ & $\begin{array}{c}\text { Pre-trial } \\
(\mathrm{g})\end{array}$ & $\begin{array}{c}\text { Final } \\
(\mathrm{g})\end{array}$ \\
\hline P. $v$. coquereli: & & & & & & & \\
Jovian & $\mathrm{M}$ & 2 & $04 / 10 / 94$ & 3,470 & 3,510 & 3,470 & 3,370 \\
Julian & $\mathrm{M}$ & 3 & $03 / 04 / 93$ & 4,030 & 4,170 & 3,920 & 3,730 \\
Marcella & $\mathrm{F}$ & $>15$ & WC $1984^{\mathrm{a}}$ & 4,600 & 4,600 & 4,350 & 4,190 \\
Nero & $\mathrm{M}$ & 1.5 & $12 / 04 / 94$ & 2,360 & 2,580 & 2,420 & 2,390 \\
Paulina & $\mathrm{F}$ & 5.5 & $01 / 24 / 91$ & 3,890 & 3,800 & 3,760 & 3,800 \\
Valentinian & $\mathrm{M}$ & 4.5 & $11 / 02 / 91$ & 4,340 & 4,250 & 4,210 & 3,680 \\
P. tattersalli: & & & & & & & \\
Agrippa & $\mathrm{M}$ & $>10$ & WC 1987 & 3,260 & 3,550 & 3,350 & 3,240 \\
Messilina & $\mathrm{F}$ & $>10$ & WC 1993 & 3,180 & 3,040 & 3,000 & 3,020 \\
Titus & $\mathrm{M}$ & $>5$ & WC 1993 & 3,280 & 3,080 & 2,930 & 2,980 \\
\hline
\end{tabular}

*Initial weights recorded on week 1 for both species, weight two, three, and four were recorded on weeks 7 , 8, and 9 for P. v. coquereli and on weeks 11, 12, and 13 for P. tattersalli.

${ }^{a} \mathrm{WC}$, wild caught; age of animal was estimated at time of capture. 
Diet Digestibility in Propithecus / 239

lowing a pulse dosage with markers for digesta passage. Owing to the small size of the captive Propithecus population, selection of individual animals used in this experiment was based on animal availability.

\section{Experimental Protocol}

For 5 days, the diet normally offered these animals, which included a mixture of a commercial biscuit (Mazuri Leafeater Primate Diet \#5672, Purina Mills, Inc., St. Louis, MO), fruits, vegetables, and locally harvested leaves, was weighed and recorded, along with quantity consumed. The daily intakes of this pre-trial diet were used as the set point from which to gradually switch to the experimental diet. Day 1 refers to the beginning of diet changeover.

On day 1 , animals were manually restrained and $3 \mathrm{~mL}$ of blood was drawn from the femoral vein. The blood was centrifuged (Beckton Dickenson Compact II Centrifuge) at room temperature for ten minutes at $1,163 x$ in a serum separator tube, and the serum was collected and stored frozen at $-20^{\circ} \mathrm{C}$ for further analysis. All animals were then weighed and returned to their usual housing. A stepwise diet change was begun and continued through week 5, when animals were consuming the commercial biscuit at $85 \%$ of DMI and Rhus copallina (winged sumac) leaves at $15 \%$ of DMI.

The first four ingredients of the Mazuri biscuit were soybean meal, ground soybean hulls, ground yellow corn, and corn gluten meal, and nutrient levels met NRC requirements for non-human primates [NRC, 1978]. At a DMI ratio of 85\% Mazuri biscuit to $15 \%$ sumac leaves, both species were consuming a diet of approximately $25 \%$ crude protein (CP), 34\% neutral detergent fiber (NDF), and $22 \%$ acid detergent fiber (ADF) despite slight differences in sumac chemical composition (Table II). The gross energy of the total diet was an average of $4.52 \mathrm{kcal} / \mathrm{g}$. After refusals were collected at 0800, the animals received the biscuit portion of the diet at 0900 and the sumac leaves at 1400 daily. All animals throughout the remainder of the experiment consumed this diet. Amounts offered were adjusted daily based on the previous day's intake to maintain the 85:15 ratio. Food intakes were recorded daily as amount offered minus refusals, and animal weights were recorded weekly.

At the beginning of week 6 , six $P . v$. coquereli were weighed and had $3 \mathrm{~mL}$ of blood drawn and processed as described above. The animals were placed indi-

TABLE II. Chemical Components of Diet Fed Propithecus verreauxi coquereli and Propithecus tattersalli*

\begin{tabular}{lccccc}
\hline Diet component & Dry matter & Crude protein & NDF & ADF & Gross energy \\
\hline $\begin{array}{l}\text { Mazuri biscuit } \\
\text { Sumac }\end{array}$ & $92.0 \pm .1$ & $28.1 \pm .3$ & $33.3 \pm .3$ & $20.4 \pm .5$ & $4.5 \pm .4$ \\
$\begin{array}{l}\text { P. } v . \text { coquereli }^{\mathrm{b}} \\
\text { Sumac }\end{array}$ & $46.1 \pm 1.0$ & $11.7 \pm .01$ & $38.0 \pm .3$ & $30.0 \pm .2$ & $4.8 \pm .4$ \\
$P$. tattersalli $^{\mathrm{b}}$ & $48.3 \pm .1$ & $10.3 \pm .01$ & $40.6 \pm .01$ & $27.5 \pm .01$ & $4.7 \pm .01$ \\
Total diet $^{\mathrm{c}}$ & & & & & \\
$\quad P$. v. coquereli & 85.1 & 25.7 & 34.0 & 21.8 & 4.6 \\
$P$. tattersalli & 85.4 & 25.4 & 34.4 & 20.5 & 4.5 \\
\hline
\end{tabular}

*DM is expressed as a percentage, and crude protein, NDF, and ADF are expressed as percentage of dry matter. Gross energy is expressed as kcal/gram of dry matter. All values reported as the mean $\pm \mathrm{SE}$.

${ }^{\mathrm{a}} \mathrm{n}=4$.

${ }^{\mathrm{b}} \mathrm{n}=2$; sumac fed to each respective species.

${ }^{c}$ Total diet, expressed on a dry matter basis, is $85 \%$ commercial biscuit and $15 \%$ sumac. 


\section{0 / Campbell et al.}

vidually in laboratory research cages $(72 \mathrm{~cm} \times 92 \mathrm{~cm})$ that allowed for the separation of urine and feces. At the beginning of week 7 , animals were weighed and $3 \mathrm{~mL}$ of blood was drawn and processed as described previously. A fresh fecal sample was collected for determination of pre-dosage cobalt and chromium concentrations. They were then dosed with $1 \mathrm{~mL}$ of Co-EDTA by mouth to measure liquid digesta passage (total cobalt $=.02 \mathrm{~g} / \mathrm{mL}$ ) and returned to the laboratory cages. They were offered "dough balls" of ground commercial biscuit containing chromium-mordanted fiber made from the biscuit to measure particulate digesta passage. Each portion contained $.36 \mathrm{~g}$ of the mordanted biscuit $(8,235 \pm 553 \mu \mathrm{g}$ chromium/g mordanted fiber). Before dosage, the chromium mordant made from the commercial biscuit was analyzed for chromium concentration by atomic absorption spectrophotometry by using an air acetylene flame and a wavelength of 359.7 nm (Perkin Elmer Atomic Absorption Spectrophotometer, Norwalk, CT). All animals consumed their dosages within $30 \mathrm{~min}$.

Following marker dosage, all feces were collected every $3 \mathrm{hr}$ for the first 3 days, and every $6 \mathrm{hr}$ for the next 4 days. Feed refusals were collected daily at 0800. Daily feed offered and refusals were combined and a representative sample was taken. All collected samples (refusals and feces) were labeled and frozen at $-20^{\circ} \mathrm{C}$ until analysis. On day 8 , animals were weighed, a final $3 \mathrm{~mL}$ blood sample was taken, and they were released back into their usual housing.

At the beginning of week 9 , the $P$. tattersalli were weighed and had $3 \mathrm{~mL}$ of blood drawn and processed as described above. Animals were then transferred to the laboratory research cages. At the beginning of week 10 between 0900 and 1000, the animals were weighed, $3 \mathrm{~mL}$ of blood were drawn, and a recent fecal sample was collected. Animals were dosed and collection made as described previously.

\section{Chemical Analyses}

Dry matter of the commercial biscuit, feed refusals, and sumac was determined by drying through placement in a forced air oven for $16 \mathrm{hr}$ at $65^{\circ} \mathrm{C}$ and then placing samples in a vacuum oven for $5 \mathrm{hr}$ at $65^{\circ} \mathrm{C}$ to remove the remaining moisture. Dry matter of feces was determined by drying through placement in a freeze drier at $40^{\circ} \mathrm{C}$ for $24 \mathrm{hr}$. The NDF and ADF levels in the commercial biscuit, feed refusals, sumac, and feces were determined using a modified version of the Van Soest method of fiber analysis [1967] developed by Ankom Technologies (Fairport, NY). Nitrogen in the feed, refusals, and feces was determined by using the Kjeldahl method of nitrogen analysis [AOAC, 1990]. Energy values of feed, refusals, and feces were analyzed using an adiabatic bomb calorimeter (Parr Instrument Co., Moline IL).

The serum non-esterified fatty acids (NEFA) were quantitated using an enzymatic assay (Wako Chemicals, Richmond, VA). Serum urea values were analyzed with a direct assay for the determination of urea [Crocker, 1967]. Serum glucose was analyzed by using a membrane immobilized enzyme system (YSI Model 2700 Select Biochemistry Analyzer, Yellow Springs, OH). Samples collected to determine transit time (TT) and mean retention time (MRT) of the chemical markers were analyzed for cobalt and chromium concentration by the NC State Nuclear Engineering department via neutron activation analysis [Pond et al., 1985]. Concentration values obtained were used to determine TT, or the time of first appearance in the feces and MRT or the average amount of time the marker was retained in the gut [Wrick et al., 1983; Caton et al., 1996]. The equation used to calculate MRT was MRT $=\Sigma \mathrm{MiTi} / \Sigma \mathrm{Mi}$, where $\mathrm{Mi}$ is the concentration of marker recovered in $\mu \mathrm{g} / \mathrm{g}$ and $\mathrm{Ti}$ is the time in hours of marker recovery. 
Diet Digestibility in Propithecus / 241

\section{Statistical Analysis}

Statistical analysis was conducted by using the Generalized Linear Models Procedure of SAS (SAS Statistical software, Cary, NC). The experiment was set up as a completely randomized design, and replicates were the animals. Time comparisons of blood variables were made by using a split plot in time. The main plot was species, and the subplot was time and time $\mathrm{x}$ species. To test species differences, animal (species) was used as an error term.

\section{RESULTS}

\section{Dry Matter Intake and Digestibility}

There were no significant differences between species (Tables III and IV) for any of the measured variables. The DMI varied considerably across individual animals; however the intake ratio of $85 \%$ biscuit to $15 \%$ sumac remained constant for all animals due to daily adjustment. Fecal consistency remained normal throughout the experiment.

The NRC lists intake energy (IE) requirements for adult Old World primates as "up to $100 \mathrm{kcal} / \mathrm{kg}$ body weight per day" [NRC, 1978]. Those animals with higher DMIs met this IE requirement (see Table III). However, the NRC values are based on few animals and they do not differentiate prosimian requirements from those of other Old World primates.

\section{Marker Recovery, Transit Time, and Mean Retention Time}

Chromium recovery for $P$. v. coquereli and $P$. tattersalli was $82.4 \pm 6.2 \%(\mathrm{n}=6)$ and $75.4 \pm .2 \%(\mathrm{n}=3)$, respectively. Cobalt recovery for $P$. $v$. coquereli and $P$. tattersalli was $46.7 \pm 5.5 \%(\mathrm{n}=6)$ and $38.8 \% \pm 1.7 \%(\mathrm{n}=3)$, respectively. Since all animals readily consumed all of the Co-EDTA by syringe, recovery may have been low because the animals absorbed a significant portion of the cobalt.

Transit times of 17-18 hr reported (Table IV) are based on a mean, but that value most likely does not reflect an actual average TT for two reasons. First, once the animals had established a sleeping site, they rarely moved around or defecated until the following morning. Caton [1996] discussed this issue when conducting marker passage trials with common marmosets and its influence on passage results. Second, the markers appeared in the feces of three animals within $8 \mathrm{hr}$ and did not appear in the feces of the other four animals until the next morning or at least $20 \mathrm{hr}$ after dosage. Therefore because of the sleeping pattern

TABLE III. Daily Dry Matter Intake and Energy Consumed Per Unit Body Weight by Propithecus spp.*

\begin{tabular}{lcc}
\hline Variables & P. v. coquereli $^{\mathrm{a}}$ & ${\text { P. } \text { tattersalli }^{\mathrm{b}}}^{\mathrm{b}}$ \\
\hline Dry matter intake & & \\
$\quad$ Grams & $74.2 \pm 8.4$ & $56.8 \pm 11.9$ \\
$\quad$ Grams per kgBW & $21.8 \pm 4.0$ & $18.5 \pm 5.6$ \\
Energy consumed & & \\
Intake energy, kcal/kgBW & $100.1 \pm 18.17$ & $83.1 \pm 25.70$ \\
Digestible energy, kcal/kgBW & $64.5 \pm 11.27$ & $53.6 \pm 15.94$ \\
Digestible energy, kcal/kgBW.75 & $87.3 \pm 13.56$ & $71.0 \pm 19.17$ \\
\hline
\end{tabular}

*All values reported as the mean $\pm \mathrm{SE}$.

${ }^{\mathrm{a}} \mathrm{n}=6$.

${ }^{b} \mathrm{n}=3$. 


\section{2 / Campbell et al.}

TABLE IV. Digestibility, Transit Time (TT), and Mean Retention Time (MRT) Values for Propithecus sp.*

\begin{tabular}{lcc}
\hline Variables & P. v. coquereli & \\
\hline Digestibility, \% & ${\text { P. } \text { tattersalli }^{\mathrm{b}}}^{\mathrm{a}}$ \\
$\quad$ Dry matter & $65.7 \pm .01$ & \\
Crude protein & $63.4 \pm .02$ & $65.6 \pm .01$ \\
NDF $^{\mathrm{c}}$ & $39.9 \pm 1.6$ & $62.3 \pm .02$ \\
ADF $^{\mathrm{s}}$ & $37.7 \pm 2.1$ & $43.3 \pm 2.1$ \\
Energy $_{\text {Chromium }}^{\mathrm{d}}$ & $65.1 \pm 1.9$ & $31.9 \pm 2.8$ \\
TT, hr & & $64.6 \pm 1.2$ \\
MRT, hr & $17.0 \pm 4.0$ & \\
Cobalt & $31.3 \pm 3.8$ & $20.0 \pm 4.8$ \\
TT, hr & & $36.3 \pm 4.7$ \\
MRT, hr & $17.0 \pm 4.0$ & \\
\hline
\end{tabular}

*All values reported as mean $\pm \mathrm{SE}$.

${ }^{\mathrm{a}} \mathrm{n}=6$.

${ }^{\mathrm{b}} \mathrm{n}=3$.

${ }^{\mathrm{c}} \mathrm{NDF}$, neutral detergent fiber; $\mathrm{ADF}$, acid detergent fiber.

${ }^{\mathrm{d}} \mathrm{Cr}$, mordanted fiber and Co-EDTA were administered to estimate passage of particle and liquid phase digesta, respectively.

described above, the only true TT values obtained were for the animals that had marker in the feces at $8 \mathrm{hr}$. These values are a low estimate of the average value, however, since fecal samples taken from other animals during the same time period did not contain markers. The percentage excretion of marker vs. time across all animals is shown in Figure 1.

\section{Serum Glucose, Urea, and NEFA Values}

Serum glucose, urea, and NEFA values obtained across all four time periods are reported in Table V. No significant differences were noted across time, or between species for serum glucose values. Urea values increased over time $(P<$. $01)$ and NEFA values both significantly varied with time and showed a time $\mathrm{x}$ species interaction $(P<.05)$. The NEFA values increased across all four periods for $P$. $v$. coquereli and increased through the first three periods then decreased in the last period for P. tattersalli.

\section{DISCUSSION}

Values obtained for DM, NDF, and ADF digestibility are similar to those reported for Alouatta spp. fed a similar diet [Edwards, 1995]. Alouatta spp. had digestibility values within the ranges of $60-70 \%$ for DM, $40-47 \%$ for NDF, and $35-40 \%$ for $\mathrm{ADF}$ when fed either a $15 \%$ or $30 \% \mathrm{ADF}$ diet [Edwards, 1995]. The digestible energy intake per unit of metabolic body weight (DEI $/ \mathrm{kg}^{75}$, Table III) for $P$. tattersalli appears low in comparison with the value obtained for $P$. $v$. coquereli; however the difference is not significant given the sample size and the high degree of variation among individual subjects. Values obtained for $P$. $v$. coquereli are comparable to Edwards' [1995] reported DEI/kg ${ }^{.75}$ for Alouatta spp.: $92.7 \mathrm{kcal} / \mathrm{kg}^{.75}$ on a $15 \% \mathrm{ADF}$ diet and $98.2 \mathrm{kcal} / \mathrm{kg}^{.75}$ on a $30 \% \mathrm{ADF}$ diet.

Cobalt recovery has been reported as lower than chromium and the Co-EDTA complex is considered less stable in the gastrointestinal tract [Kennelly et al., 1982]. Uden et al. [1980] suggested that cobalt recovery might be considerably lower in animals with a large, well-developed cecum designed for absorption of 
Diet Digestibility in Propithecus / 243

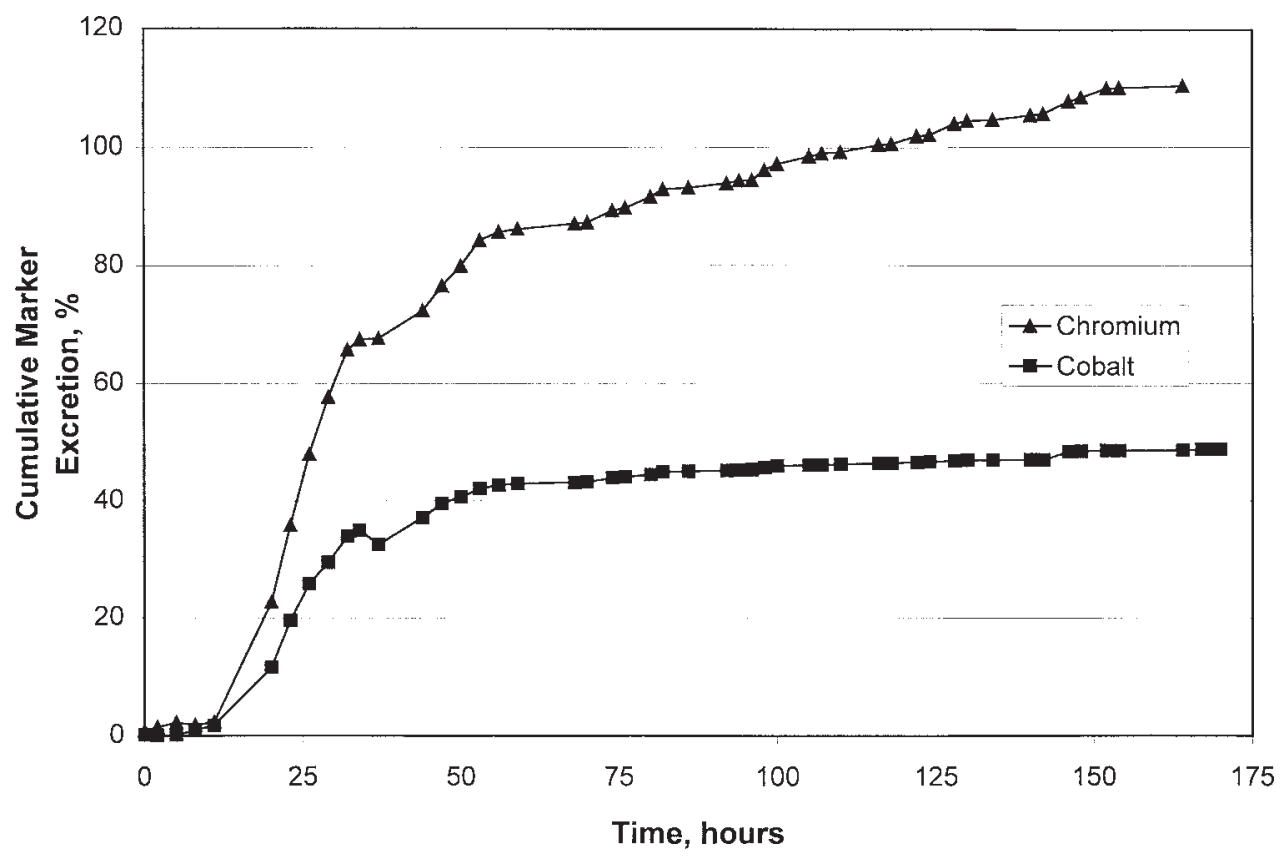

Fig. 1. Cumulative chromium $(\mathrm{SEM}=23.27 \%)$ and cobalt $(\mathrm{SEM}=11.44 \%)$ excretion vs. time in hr across all animals. $(n=9)$

feed components. For instance, $24 \%$ of the cobalt administered orally to rabbits appeared in the urine, indicating that these animals absorbed a substantial amount. Because of problems associated with total collection of urine, it was not analyzed for cobalt content; however the low recovery observed here indicates that cobalt-EDTA may not be an appropriate marker for some lemur species.

TABLE V. Serum Glucose, Urea, and Non-Esterified Fatty Acid (NEFA) Concentrations in Propithecus spp. at Four Sampling Times

\begin{tabular}{|c|c|c|c|}
\hline & Glucose (mM) & Urea $(\mathrm{mM})$ & NEFA $(\mathrm{mM})$ \\
\hline \multicolumn{4}{|c|}{ P. verreauxi coquereli ${ }^{\mathrm{a}}$} \\
\hline Initial & 5.7 & 9.3 & .400 \\
\hline Pre-caging & 6.5 & 9.0 & .377 \\
\hline Pre-trial & 6.7 & 11.4 & .430 \\
\hline Final & 6.3 & 11.9 & .672 \\
\hline $\mathrm{SE}^{\mathrm{c}}$ & .33 & .82 & .048 \\
\hline \multicolumn{4}{|l|}{ P. tattersalli ${ }^{\mathrm{b}}$} \\
\hline Initial & 6.4 & 7.3 & .111 \\
\hline Pre-caging & 6.0 & 9.3 & .251 \\
\hline Pre-trial & 6.3 & 11.3 & .597 \\
\hline Final & 6.6 & 15.2 & .367 \\
\hline $\mathrm{SE}$ & .47 & 1.2 & .068 \\
\hline $\mathrm{AOV}^{\mathrm{d}}$ & NS & $\mathrm{T} P<.01$ & $\mathrm{~T} P<.05, \mathrm{~S} * \mathrm{~T} P<.01$ \\
\hline
\end{tabular}

${ }^{\mathrm{a}} \mathrm{n}=6$ for $P . v$. coquereli.

${ }^{\mathrm{b}} \mathrm{n}=3$ for $P$. tattersalli.

${ }^{\mathrm{c}} \mathrm{SE}$ from least squared means analysis.

${ }^{\mathrm{d}}$ Analysis of variance: $\mathrm{T}=$ time, $\mathrm{S} * \mathrm{~T}=$ species * time, $\mathrm{NS}=P>.10$. 


\section{4 / Campbell et al.}

The TT values of 17-18.5 hr for the Propithecus spp. are much higher than those reported for Varecia spp. [Edwards, 1995] or Eulemur fulvus [Ganzhorn, 1986]. They are similar in comparison to TT values of 15-16 hr for Co-EDTA and 15-23 hr for chromium mordanted fiber obtained for Alouatta spp. fed either a $15 \% \mathrm{ADF}$ or a $30 \% \mathrm{ADF}$ diet [Edwards, 1995]. The MRT values of 30-34 hr obtained across both species were not different for either the chromium mordanted fiber or the Co-EDTA. These results suggest that both Propithecus spp. retain feeds in the gut for a similar time period, although larger sample numbers might show differences. Regardless, the length of time the digesta resided in the gut indicates significant hind gut fermentation. For example, Edwards [1995] reported MRTs for Alouatta spp. of 34-38 hr for Co-EDTA and 38-40 hr for chromium mordanted fiber, and many other post-gastric herbivores show similar values [Stevens \& Hume, 1995].

Values obtained for the MRT of mordanted fiber and the Co-EDTA indicate that the particulate and liquid digesta did not have different retention times in the gut. This may be a factor of the fiber particle size present in the Mazuri biscuit. Further investigation using natural feedstuffs, longer fiber particles, or a better liquid marker might yield different results.

When serum glucose values are compared with those obtained from physiologically normal captive $V$. variegata $[6.48 \mathrm{mM}$ glucose, $\mathrm{n}=31$; Karesh \& Olsen, 1985], Daubentonia madagascarensis [6.07 mM glucose, $\mathrm{n}=6$; Feeser, 1994] and wild P. tattersalli [7.65 mM, glucose, $\mathrm{n}=28$; Garell, 1990], they appear to be within reported ranges.

Serum urea values reported for $V$. variegata [3.14 mM urea, n=31; Karesh \& Olsen, 1985], D. madagascarensis [1.91 mM urea, $\mathrm{n}=6$; Feeser, 1994], and wild captured $P$. tattersalli [2.67 mM urea, n=28; Garell, 1990] all are lower than the values obtained in this study. The pre-trial diet, primarily composed of fruits, vegetables, and harvested browse, was low in protein relative to the experimental diet. A rough estimate of the average crude protein (CP) content of the pretrial diet was $11 \%$ to $14 \%$. Based on intake, it provided approximately $3.4 \mathrm{~g} / \mathrm{kg}$ of body weight compared to $5.5 \mathrm{~g} / \mathrm{kg}$ of body weight provided by the experimental diet. The NRC [1978] lists a CP requirement of 3.5 to $4.5 \mathrm{~g} / \mathrm{kg}$ of body weight for adult Old World primates.

Given the limited number of values with which to compare and the absence of captive normal values for Propithecus, it is difficult to speculate as to whether the urea values obtained in this study are abnormally high. If so, whether this is due to catabolism of absorbed amino acids due to high levels of protein in the diet, or to mobilization of protein stores to provide energy is unclear. Urea values increase in both situations [Kaneko,1989].

The NEFA values obtained are average to high when compared to reported ranges for most animals [.3 to .5 mM, Kaneko, 1989] but no values from prosimian species are available. It is difficult to assess their relationship to energy balance; however the animal with the lowest DMI had the highest NEFA value. Another issue to consider when interpreting the values for glucose and NEFA is that serum levels of these metabolites can rapidly increase in response to elevated serum epinephrine in a stressed animal [Burtiss \& Ashwood, 1996; Kaneko, 1989]. Manual restraint during blood draw is stressful and can last for minutes, allowing adequate time for epinephrine to have an impact on the serum metabolites. Serum glucose values obtained did not appear abnormally high, which argues against a stress effect, however that could be due to glycolysis taking place in the serum tube before samples were centrifuged.

The feeding ecology of many Propithecus is similar to that of other Indriids 
Diet Digestibility in Propithecus / 245

[Avahi; Hladik, 1978], Alouatta [Milton et al., 1980; Milton, 1981; Edwards, 1995], and members of the Colobine family [Davies \& Oates, 1994; Edwards, 1995]. However, while colobines possess a pregastric fermentation chamber [Davies \& Oates, 1994; Stevens \& Hume, 1995], the Propithecus, Avahi, and Alouatta spp. possess a post-gastric fermentation chamber [Hladik, 1967, 1978, Stevens \& Hume, 1995]. Depending on the species, it can include the colon, the cecum, or both [Stevens \& Hume, 1995]. Values obtained for both digestibility and marker passage are commensurate with those reported for Alouatta spp., another post-gastric folivorous primate, but lower than values reported for colobines [Edwards, 1995; Watkins, 1985]. Therefore, digestibility and passage data obtained suggest that these two Propithecus species show adaptations to a folivorous diet similar to other post-gastric herbivores.

Finally, while numbers were limited and intakes were variable, $P$. v. coquereli and $P$. tattersalli showed similar digestibility and digesta passage when fed a similar diet. Therefore differences observed in captive fitness are not likely to be a result of different gastrointestinal physiology.

\section{CONCLUSIONS}

1. There were no observed digestibility or passage differences between species.

2. Digestibility values for both species were approximately $65 \%$ for DM, CP, and energy, and $40 \%$ and $35 \%$, respectively, for NDF and ADF.

3. Transit times were 17-18 hr for chromium mordant and Co-EDTA, and mean retention times were and $30-34 \mathrm{hr}$ for both markers.

4. Results are similar to those obtained for Alouatta spp., also post-gastric primate folivores.

5. Co-EDTA is not an ideal marker for determining passage in these species.

\section{ACKNOWLEDGMENTS}

The authors thank Purina Mills, Inc. for providing funding for this project and the staff of Duke University Primate Center for providing valued assistance. Specifically, thanks go to Kelly M. Glenn, Cathy Williams, DVM, and William Hess for all the effort put forth to ensure successful and safe completion of this project. Andy Tobias, Heather Lynch, and Jennifer Hurley deserve thanks for volunteering their help during collections, and Dennis Herman for providing assistance in the laboratory.

\section{REFERENCES}

Association of Official Analytical Chemists. 1990. Official methods of analysis, 15th edition. AOAC: Washington D.C.

Burtiss CA, Ashwood ER. 1996. Tietz fundamentals of clinical chemistry. Philadelphia: W.B. Saunders Co.

Caton JM, Hill DM, Hume ID, Crook GA. 1996. The digestive strategy of the common marmoset, Callithrix jacchus. Comp Biochem Physiol 114A:1-8.

Crocker CI. 1967. Rapid determination of urea nitrogen in serum or plasma without deproteinization. Am J Med Technol 33:361- 365 .

Davies AG, Oates JF. 1994. Digestive physiology. In: Colobine monkeys: their ecology, behavior, and evolution. Cambridge University Press. p 230-249.

Edwards MS. 1995. Comparative adaptations to folivory in primates. Ph.D. dissertation. Michigan: Michigan State University Press.

Feeser P. 1994. Haematology and serum biochemistry values in Aye-Ayes (Daubentonia madagascarensis) at the Duke University Primate Center. Folia Primatol 62:175-178.

Ganzhorn JU. 1986. Feeding behavior of Lemur catta and Lemur fulvus. Int J Primatol 7:17-29. 


\section{6 / Campbell et al.}

Garell DM. 1990. Hematology and serum chemistry values of free-ranging golden crowned sifaka (Propithecus tattersalli). Proc Am Assoc Zool Veterinar. p 133-145.

Hill O. 1953. Primates-strepsirhini. Edinburgh: Edinburgh Press.

Hladik CM. 1967. Surface relative du tractus digestif de quelques primates: morphologie des villosites intestinales et correlations avec le regime alimentaire. Mammalia 31:120-147.

Hladik CM. 1978. Adaptive strategies of primates in relation to leaf eating. In: Montgomery GG, editor. The ecology of arboreal folivores. Washington D.C.: Smithsonian Institution Press. p 373- 395.

Kaneko JJ. 1989. Clinical biochemistry of domestic animals. San Diego CA: Academic Press.

Karesh WB, Olson TP. 1985. Hematology and serum chemistry values of juvenile and adult ruffed lemurs (Varecia variegata). J Med Primatol 14: 5-12.

Kay R, Hylander W. 1978. The dental structure of mammalian folivores with special reference to Primates and Phalangeroidea. In: Montgomery GG, ed. The ecology of arboreal folivores. Washington D.C.: Smithsonian Institution Press. p 173-191.

Kennelly JJ, Turner BV, Apps MJ. 1982. Determination of non-radioactive liquid phase markers, Co-EDTA and Cr-EDTA, by neutron activation analysis. J Sci Food Agric 33:1235-1243.

Meyers D. 1993. The effects of resource seasonality on behavior and reproduction in the Golden Crowned Sifaka in three Malagasy forests. Ph.D. dissertation. Duke University.

Milton K, Van Soest PJ, Robertson JB. 1980 Digestive efficiencies of wild howler monkeys. Physiol Zool 53:402-409.

Milton K. 1981. Food choice and digestive strategies of two sympatric primate species. Am Nat 117:496-505.

Mittermeier R, Konstant W, Nicoll M, Langrand O. 1992. The lemurs of Madagascar: an action plan for their conservation. International Union of Conservation of Nature and Natural Resources.

National Research Council. 1978. Nutritional Requirements Of Nonhuman Primates, Number 14. Washington D.C. National Academy of Sciences.

Pond KR, Ellis WC, James WD, Desuwysen AG. 1985. Analysis of multiple markers in nutritional research. J Dairy Sci 68:745-750.

Richard A. 1977. The feeding behavior of Propithecus verreauxi. In: Clutton-Brock $\mathrm{TH}$, editor. Primate ecology: studies of feeding and ranging behavior in lemurs, monkeys and apes. London: Academic Press. p 71-96.

Stevens CE, Hume ID. 1995. Comparative physiology of the vertebrate digestive system. Cambridge: Cambridge University Press.

Tattersall I. 1982. The primates of Madagascar. New York: Columbia University Press.

Uden P, Colucci PE, Van Soest PJ. 1980. Investigation of chromium, cerium, and cobalt as markers in digesta: rate of passage studies. J Sci Food Agric 31: 625-632.

Van Soest PJ. 1967. Development of a comprehensive system of feed analysis and its application to forages. J Anim Sci 26:119-127.

Watkins BE, Ullrey DE, Whetter PA. 1985. Digestibility of a high fiber biscuit based diet by black and white colobus. Am J Primatol 9:137-144.

Wrick KL, Robertson JB, Van Soest PJ, Lewis BA, Rivers JM, Roe DA, Hackler LR. 1983. The influence of dietary fiber source on human intestinal transit and stool output. J Nutrition 113:1464-1479. 